\title{
The Gang's All Queer: The Lives of Gay Gang
}

\section{Members}

Vanessa R Panfil (2017), The Gang's All Queer: The Lives of Gay Gang Members, New York: New York University Press,

303pp

ISBN: 978-1-4798-7002-8 (hardback)

ISBN: 978-1-4798-7002-1 (paperback)

Anna Bray, Sociology Department, University of Warwick

How is masculinity negotiated for gay men in gangs? The question that Panfil asks throughout this book provides a disruption of the 'heterosexual imaginary' of assumed heterosexuality, hyper-masculinity and hyper-sexuality within gangs. Illustrating her qualitative analysis with in-depth interviews and ethnographic fieldwork of 53 queer gang members in Ohio, she considers how masculinity is constantly negotiated for queer gang members, rendering their invisibility within literature across the fields of criminology, sociology and queer theory no more.

Utilising the theoretical framework of symbolic interactionism - the construction of identity through the process of 'meaning-making' - the book is separated neatly into three parts. Part one consists of understanding the construction of gay identity itself. It also looks at the early life experiences of these men and the impact this has had upon identity-making today. Within part two, gay gangs and hybrid gangs (those that have a high quantity of gay members) are discussed, looking at the experiences of men within these gangs. Following on from this, in the third and final part, Panfil considers how resistance to victimisation is negotiated through 'fighting back' to antigay harassment. Throughout the whole book, she expertly interweaves a comparison of the composition of gangs, which may consist of gay, lesbian or bisexual (GLB) members, experiences within them and the types of gangs (whether they are gay, straight or hybrid), underlying the overarching structure of gangs and how identity is negotiated within them.

Firstly, the cultural messages that become internalised within queer communities are discussed by looking at each of the gang member's plural identities and how each of 
these are negotiated within a broader context of gang membership. These involve their own understandings of heteronormativity, what it is like to have a sexual identity deemed 'other' and whether it is considered 'acceptable' to demonstrate their sexuality. Panfil considers the fear surrounding revealing their sexual identity, including anxieties around their family's perceptions, and discusses how this becomes embodied to prevent displays of 'feminine' behaviour. There is also an association here that links cultural perceptions of homosexuality with being white where the intersections between race, sexuality and being a gang member are discussed.

Following this, Panfil discusses the implications of the differing uses of the term 'fag', including its historicisation and subsequently its boundaries of acceptable usage. For example, it may be used as a slur against other gay gang members to criticise feminine or flamboyant behaviour. It therefore represents a space between what are 'acceptable' presentations of masculinity and what are not that is used to police behaviour. This can also be used to demarcate internalised homophobia within gay gangs themselves; however, the extent to which the term has been claimed as a form of affection has also been discussed. Panfil also considers queer space through visiting the vogue ball, where hegemonic understandings of masculinity and heteronormativity are defied.

Within the final part of the book, Panfil discusses resistance through considering how stereotypes and taking part in illegal activities are balanced, as well as the construction of 'appropriate' masculinity and gay identity within structural inequalities. In order to combat harassment or homophobia, gang members are able to 'fight back'. They do this by reclaiming terms such as 'fag' in order to self-identity as queer, but also as a way to protect themselves from future harassment. Panfil also discusses other challenges, however, such as overcoming stereotypes of what it means to be a gang member and the lifestyle it involves. They have to balance illegal activities with an image of legitimate work while negotiating the identity of what it means to be a 'real' man through employment. While the majority of gang members state they would prefer legal forms of work, it is evident this is not always possible due to being underpaid or having previously received criminal convictions.

Panfil is an assistant professor of sociology and criminal justice at Old Dominion University as well as having completed her $\mathrm{PhD}$ in criminal justice. Identifying as a queer feminist herself and being involved with LGBT activism, she has a strong expert, as well as personal, background knowledge of the subject area at hand. The text is structured logically and in an accessible style, explaining the definitions of 
sociological and criminological terms as it goes along, making it easily accessible to all.

In fact, one could argue that the book is almost faultless, with justifications used throughout each stage for use of the chosen terminology - such as 'gay' being used as an umbrella term for GLB - and prioritising the terms the gang members themselves use. It also is a largely reflexive research account in that Panfil considers how each of the themes discussed relate to herself, including how being around gangs and their terminology influenced her own vocabulary and behaviour, and the moral concerns of this. Perhaps the only downfall then is the lack of explanation in the background research on gang members within the wider literature that readers newer to the subject area might be less familiar with, particularly around the underground economy.

However, this book ultimately fills an existing gap within criminological and sociological research on transgression by providing a riveting look at identity construction, through considering what it means to be a 'real' man, the implications of boundary maintenance (such as the ways we try to present our identity in how we would like to be perceived), as well as other aspects of queer gang members' lives. It allows one to question deeply held underlying assumptions and subconscious biases around masculinity and disrupts negative discourses surrounding lack of agency and victimisation of gay men. As Panfil argues, there is something about 'recent cultural history that has facilitated gay and bisexual gang members in straight gangs feeling comfortable enough to talk with media, documentarians and researchers.' This must be utilised to question existing practice and to allow for a more tolerant and understanding society, with evidence to suggest these practices and subjectivities even extend beyond gang membership into wider social realms. The Gang's All Queer begs the question of how we can redefine gangs and understand crime through a queer lens as well as providing a long-awaited and much-needed attention to the complexities that exist within seemingly contrasting sexual identities and gang membership.

\section{Kristen Davis, Department of Criminology, Monash University}

Vanessa R Panfil presents an unusual and controversial thesis in her study The Gang's All Queer: The Lives of Gay Gang Members in which she considers gay men not as victims, but as perpetrators of gang violence. This thesis comes as a breath of fresh air in a field dominated by studies of the victimisation of gay men at the hands of straight or latently gay men, many of whom operate in gangs. Within the discourses of 
sociology and criminology, gay men are also often perceived in the context of samesex intimate partner violence or in offences that are sexual in nature, for example, sex work.

In The Gang's All Queer, the focus moves from these well-worn areas to examine the lives of so-called 'gay gang members' - sometimes referred to as 'homo-thugs' - whose gay identities subvert traditional understandings of gangs and of gang members. Most interestingly, Panfil provides us with a portrait of gay men as violent in their response to homophobic abuse, instead of as passive victims as is usually the case. The concept of 'fagging out' was particularly interesting, as it presents gay men as actively attacking those who taunt them with slurs such as 'fag' (189-90).

Throughout the book, Panfil has drawn heavily from face-to-face, semi-structured interviews with over 50 men, many of them self-identifying (albeit in often complex and contradictory ways) as gay or bisexual and also as 'gang members'. Panfil uses an intersectional approach, and her interviewees are portrayed as predominantly black, working-class and having some involvement with crime and the criminal justice system. She begins the study with two chapters on the ways in which gay gang members form and negotiate their identities; the next three chapters detail the experiences of men in different types of gangs: ones composed of primarily gay members, straight gangs composed of mostly straight members, and hybrid gangs composed of both gay and straight members; and concludes with two chapters discussing the various resistance strategies adopted by gay gang members in response to homophobic attacks.

Vanessa R Panfil's positioning in relation to this study is fascinating. She presents as both an outsider in relation to this project - as a privileged, white, female academic yet her lesbian identity and her obvious skills as a sociologist/ethnographer position her as that of an insider. On the one hand, Panfil's self-described 'butch' identity gains her the confidence of her participants; as a member of an 'othered' sexuality, she is assumed by the men to share in their experiences of homophobia and outsiderhood in heteronormative society. On the other, she discusses her presentation as a white woman, which contrasts dramatically with the class and race of her participants; her role as an academic only emphasises that privilege. This privilege sometimes took on a visceral edge; for instance, 'Imani joked that the only reason a "car full of negroes" didn't get stopped by police while speeding or doing illegal U-turns was because the driver was a white girl' (250). She also was treated courteously by police when she 
became lost when travelling to an interview, parked her car illegally, and asked police for directions (250).

In conclusion, this study is a ground-breaking piece of work that allows us a perspective on gay men rarely seen in academic literature. Panfil has a large sample of men from whom to draw insight into this milieu of gay gangs in Columbus, Ohio, and has provided a captivating portrait of this group of active and bellicose agents who challenge the traditional stereotypes of homosexual victimhood. It would be interesting to see a similar study conducted on lesbian/boi gangs, particularly in reference to dismantling tropes of feminine passivity.

To cite this paper please use the following details: Bray, A OR Davis, K. (2019), Panfil, Vanessa R. (2017), 'The Gang's All Queer: The Lives of Gay Gang Members', Reinvention: an International Journal of Undergraduate Research, Volume 12, Issue 1, https://reinventionjournal.org/article/view/544/. Date accessed [insert date]. If you cite this article or use it in any teaching or other related activities please let us know by e-mailing us at Reinventionjournal@warwick.ac.uk. 